\title{
THE ELECTORAL VALUE OF CONSTITUENCY ORIENTED PARLIAMENTARY QUESTIONS IN HUNGARY AND ROMANIA
}

Mihail Chiru'

\begin{abstract}
Drawing on an unique dataset that combines legislative behavior data and electoral results at two elections in Romania $(2008,2012)$ and one in Hungary $(2014)$, the study assesses the overall electoral value of parliamentary questions dealing with local issues. Our multivariate regression analyses illustrate that the effect of constituency questions is distinguishable from that of the overall parliamentary effort of the MPs. Constituency questions brought Romanian MPs significantly more votes at each of the last two elections. In Hungary, where the scope for a personal vote was much more limited at the analyzed elections, no effect is found.
\end{abstract}

Keywords: Constituency Service, Electoral Reform, Personal Vote, Parliamentary Questions, Hungary, Romania

Date of acceptance: October 22, 2017

\section{Acknowledgements}

The author is grateful to Gabor Toka, Zsolt Enyedi, Zsofia Papp, Federico Russo and the two anonymous reviewers for their useful comments and constructive suggestions on earlier drafts.

\section{Funding}

This work was supported by the Romanian Ministry of National Education, CNCS-UEFISCDI, through the project PN-II-ID-PCE-20I2-4-0644: 'Re-thinking Individual Representation: Campaign Personalization and Legislative Behaviour'; and by the Universite' catholique de Louvain through the 'MOVE-IN Louvain'Incoming Post-doctoral Fellowship, co-funded by the Marie Curie Actions of the European Commission.

${ }^{1}$ Oxford School of Global and Area Studies, University of Oxford. Email address:

mihail.chiru@area.ox.ac.uk, phone: 07518407676; postal address: 11 Bevington Road, UK, OX2 6NB. 
Despite the salience political scientists tend to project on it as main discrimination criterion for assessing the merits of various electoral systems, or as a key explanation for political events, 'direct evidence of a personal vote' is largely missing (Shugart, 2005, p. 46), or to be more precise, proofs of 'electoral rewards for cultivating a personal vote' are scarce (Martin, 2010, p. 370).

Like most other issues in individual legislative behavior research, interest in the electoral consequences of constituency service first emerged in the United States. Most of the empirical work carried on the topic in the United States in the late 1970s and in the 1980s found little or mixed statistical evidence for a positive effect of constituency service on the electoral success of incumbents (Johannes and McAdams, 198I; McAdams and Johannes, 1988; Rivers and Fiorina, 1989). However, American legislators strongly believed that constituency service pays off electorally although they were unsure about the size of this effect (Mayhew, 1974).

More recent publications argued that the contradictory results appeared mainly because of the methodological shortcomings of these studies and were instead able to point to more consistent evidence for the relation, even if this was rather indirect, drawing on aggregate levels of support (King, 1991) or analyzing voters' perceptions of incumbents instead of actual vote shares (Parker and Goodman, 2009; Box-Steffensmeier et al., 2003).

These studies and others on the same topic conducted outside the U.S. have used a large variety of indicators to measure constituency service. They range from self-reported activity from survey data (Martin, 2010) to local bills (Box-Steffensmeier et al., 2003), franking (Parker and Goodman, 2009), legislative budgets for constituency service (King, 1991), budget amendments (Arter, 20II), trips home (McAdams and Johannes, 1988; Parker and Goodman, 2009) and district office expenditures (Parker and Goodman, 2009). However, none has looked at the electoral impact of parliamentary questions on local issues, although they are used more and more as an indicator for constituency service (Martin, 20II). The article fills this gap by drawing on parliamentary question data coded systematically for their relevance to constituency welfare.

This article contributes directly to the growing scholarship attempting to reveal evidence of personal vote, by testing for the first time the electoral value of a type of legislative behavior which targets directly constituents and constituency welfare. Thus, the central research question of this study is: 'to what extent asking parliamentary questions on constituency issues helps Members of Parliament (MPs) gather more votes at the subsequent elections?'

To answer this question I analyze how the parliamentary questioning behavior of incumbent MPs affects their electoral performance in three elections taking place in Hungary (2014) and Romania (2008 and 2012). ${ }^{2}$ These three elections are highly relevant because the potential for a personal vote varied considerably. This happened due to changes in electoral system provisions and in the degree in which partisan evaluations left any space for a personal vote.

The introduction is followed by the theoretical framework and hypotheses of the study. The next section includes the research design: a presentation of the data collection, of the variables' operationalization and main descriptive statistics. This is followed by a brief section on how parliamentarians disseminate their constituency questions. Next come the regression analyses and a discussion of the effects of constituency questions on the electoral performance of the incumbents running for re-election. The conclusion synthesizes the main findings of the article and points to further directions of research.

\footnotetext{
${ }^{2}$ Unfortunately, for Hungary parliamentary question data was available only for the most recent legislative term.
} 


\section{Why would local parliamentary questions matter for electoral performance?}

The direct electoral utility of constituency service rests on two main arguments: it increases the legislator's visibility in the district and it makes constituents aware of their representative's responsiveness. Thus, constituency work helps legislators attract public recognition as constituents become more familiar with the name of their representatives (Box-Steffensmeier et al., 2003; Cover and Brumberg, 1982) and learn about their responsiveness to local needs and demands (Fiorina, 198I).

More specifically, even if the parliamentary questions on local problems do not trigger governmental action and actual solutions, MPs can still claim credit for putting these issues on the agenda (for a similar argument regarding the electoral payoff of bill initiation see: Däubler et al., 20l6). Asking constituency questions can be also framed as acting upon salient issues that other politicians have neglected.

Furthermore, this type of publicity can help representatives build the image of 'caring, active or otherwise good constituency MPs' (Bowler, 2010, p. 48I). Thus, more constituency questions will give voters the cue of a hard-working representative looking after the welfare of the district, irrespective of the actual outcome of these questions, in the same manner in which in the United States the frequency of legislator credit claiming for distributive spending is much more important than the actual size of the spending or whether the legislator even had anything to do with the spending (Grimmer et al., 20l4).

An indirect positive effect of constituency service emphasized by the literature is that it scares off high quality challengers (Cox and Katz, 1996, p. 479): the latter will be reluctant to enter in a competition with an incumbent who has developed a reputation for service, through casework and allocation responsiveness. Thus, facing weaker opponents such incumbents will lose fewer votes. This relation between constituency service and challengers has been also documented in the Hungarian case, with respect to intra-party competition. Thus, roughly $53 \%$ of the Hungarian MPs responding to the PARTIREP Survey (Deschouwer and Depauw, 20I4) agreed that reducing the efforts they make to assist voters in their dealings with public authorities would result in facing 'serious challenge in the candidate selection process', whereas only $31 \%$ disagreed.

Constituency questions can mobilize different type of votes through different vote-winning strategies. Thus, citizens who contacted the MP and received help (Parker and Goodman, 2009) in the form of an information requested through a parliamentary question or of forwarding their petition to state agencies via the same tool, will certainly be more likely to vote for her, as will be their family members. Other voters may be persuaded by learning from local media about the local MP's parliamentary questions regarding the infrastructure in the constituency or local business issues.

H.I: The more constituency questions MPs ask, the more votes they will receive at the subsequent elections.

In a nutshell, the relevance of personal vote at any given election depends on electoral system regulations (H.2) that enable citizens to reward or punish individual politicians (Carey and Shugart, 1995) and on the degree to which the strength of citizens' partisan evaluations ${ }^{3}$ leaves

\footnotetext{
${ }^{3}$ Usually, these evaluations concern the performance of incumbent parties.
} 
any space for them to take into account in their vote decisions the merits and reputations of individual candidates (H.3). Both types of factors mentioned - electoral system provisions and the strength of partisan evaluations - varied considerably at the three elections analyzed and this variation translates in a different potential for a personal vote which is bound to mediate the electoral value of constituency questions.

Although the jury is still out regarding which electoral systems is most candidate-centered (see the literature survey of André et al., 2016), most scholars tend to agree that closed list proportional representation is the system least likely to enable a personal vote. In mixed systems, the personal vote potential is likely to be higher if nominal votes predominate over list votes in the allocation of seats. Another relevant question for the personal vote potential is whether votes are pooled, transferrable or exclusive. Beyond the mechanical and psychological effects of electoral systems employed at a particular election, an electoral reform can also strengthen or weaken voters' likelihood to cast a personal ballot through what the reformers, the parties and the candidates choose to emphasize as the most relevant aspects of the reform. The 2008 elections were the first organized in Romania under an original mixed member proportional system in which all MPs were elected in SMDs, but only those who won the absolute majority of votes got their seat directly, the rest depending on the party vote at county and national level. The introduction of the single member districts after five rounds of elections conducted under closed list Proportional Representation, and the emphasis put by the electoral reform on strengthening citizen-representative linkages made a personal vote more likely than ever. While the seat allocation process cannot be detailed here (for it see Giugal et al., 2017) this electoral system had a high potential for personalization and personal vote because a good individual performance increased not only the chances of a candidate to get elected, but also the seat count for their party and their individual standing within the party. Thus, the vote pooling mechanism used meant that winning more votes helped the party win more seats without hurting co-partisans (as it would happen in open list systems).

The Hungarian electoral reform went in the opposite direction. The new electoral system adopted in December 201I abolished the county party lists and replaced the majority run-off formula with First Past The Post (FPTP) for the district mandates. The reduction in Parliament size, from 386 to 199, meant that 106 seats were allocated via FPTP in SMDs while the rest were distributed through Closed List Proportional Representation on the basis of national party lists. The elimination of the run-off decreased the incentives for a personal vote and its relevance: voters do not cast multiple votes anymore (across time, i.e. in the two rounds), which means candidates do not need to emphasize their personal reputation in the run-off to appeal to voters outside their core group (Carey and Shugart, 1995, p. 422). Another disincentive for cultivating a personal vote brought by the electoral reform was the increase in average district magnitude as experienced by individual legislators (Wallack et al., 2003) from 12.2 to $44 .^{4}$

H.2: The more the electoral system provisions favor a personal vote, the more votes will receive MPs who ask constituency questions.

\footnotetext{
${ }^{4}$ The electoral reform also introduced a bias favoring Fidesz via the change in the allocation and proportion of list seats, the elimination of the runoff for SMD elections, the change in constituency boundaries and through giving non-resident citizens the right to vote (Toka, 20I4).
} 
High unpopularity of an incumbent government fueled by poor economic performance, unfulfilled pledges or corruption scandals can have an ambivalent effect for the personal vote. On the one hand, such unpopularity would most likely fuel a partisan vote, making irrelevant considerations regarding individual candidates' political experience and personal office record. In such a situation voters would not care much about the individual merits and constituency service efforts of MPs and their vote decisions would be driven solely by the desire to punish government parties. On the other hand, government MPs might perceive a campaign centered on constituency service as their only chance to persuade some of the former supporters of their parties and be re-elected in this manner.

Moreover, if government parties have adopted high-stake or very controversial institutional reforms or policy measures during their term in office, voting would likely be based on the citizens' perceptions of these issues, while their opinions of individual MPs and legislative activities would become secondary.

The most outstanding election with respect to the two criteria mentioned above is the 2014 contest in Hungary, followed by the 2012 Romanian parliamentary election. Thus, after 2010 the Hungarian party system was transformed from a very stable two party-system (Enyedi and Toka, 2007) into a dominant party system with a weak and fragmented opposition (Toka, 20l4). Having won more than $2 / 3$ of the seats in Parliament, Fidesz-KDNP changed both the Constitution and the electoral system in a one-sided manner that avoided consensus building and followed its own interests (Toka, 20I4). The alternative to the government was weak: after many failed negotiations a center-left electoral coalition was formed under the label 'Unity', but it remained extremely divided, mainly because of personality clashes between the leaders of the five component parties: MSZP, DK, PM, MLP and Együtt 2014 (Mudde, 2014; llonszki and Várnagy, 2016). As a consequence of the institutional engineering ${ }^{5}$ and the weakness of the main alternative, Fidesz won in the April 2014 parliamentary elections all but 10 SMDs and a new constitutional majority. All in all, the Hungarian citizens' perceptions of the institutional reforms and nationalist economic policies implemented by Fidesz (Johnson and Barnes, 2015) and of the divided opposition were bound to shape their voting decisions, leaving little space for a personal vote.

In Romania, the 2012 elections were marked by the collapse of PDL, which had implemented a series of harsh austerity measures in the wake of the economic crisis. These austerity measures and a series of corruption scandals made PDL extremely unpopular, and the party lost power in April 2012 following the first successful no-confidence vote in Romania's history. In this context, the December 2012 parliamentary elections brought a landslide victory for the Social Liberal Union (USL), an alliance between the other two major parties, PSD and PNL, which obtained $59 \%$ of the votes and $66 \%$ of the seats. The last election considered, the one held in 2008 in Romania happened in the least polarized of all three contexts, following Romania's accession to the EU.

H.3: The weaker partisan evaluations are at an election, the more votes will receive MPs who ask constituency questions.

To sum up, the three samples stand for different values regarding the relevance of personal vote and one should see the strongest positive effect of constituency questions at the 2008

\footnotetext{
${ }^{5}$ Fidesz needed two times fewer votes per parliamentary mandate than Unity and three times fewer than Jobbik and LMP, the other two parties managing to win representation (Mudde 2014).
} 
elections in Romania, followed by the 2012 ones, whereas at the 2014 Hungarian elections the personal vote should be virtually irrelevant.

In addition to the hypothesized effects, I control for the effect of seven variables: overall parliamentary effort (an index of parliamentary activities salient for each legislature), electoral security at the previous elections, parliamentary experience, parliamentary office, cabinet position, gender and party affiliation. Plenty of studies failed to uncover any positive impact of parliamentary activity levels on electoral success or re-election (Däubler et al., 2016; Akirav, 20I5), while others did (Bowler, 2010). Nevertheless, it is extremely important to control for this variable in order to be confident that the analyses actually measure the electoral consequences of constituency service, and not just a proxy for the effect of parliamentary activity levels. The other variables are standard controls for models of personal vote, capturing vote earning attributes of the MPs as well as the overall space for such a vote, i.e. factoring out the votes MPs receive only for their party label.

\section{Research Design: data, variables, descriptive statistics.}

Parliamentary questions are regulated similarly in both Parliaments. Thus, there is no quorum requirement and no need for PPG approval for written questions and for interpellations. Oral questions in Hungary and the oral presentation of interpellations in Romania are subject to party control. Overall, parliamentary questions are functionally equivalent in the two settings, being used both to scrutinize the government and to raise local issues. The Hungarian parliamentary questions data set (llonszki and Papp, 2014) covers all the 5776 oral and written questions submitted between May 2010 and the end of the 2012. Roughly one fifth of these (21\%) - 1207 were constituency questions. Similarly, the Romanian data includes all the questions and interpellations asked by the members of the Chamber of Deputies in the first two years of the 2004-2008 and 2008-2012 terms. This amounts to 4644 questions and interpellations asked by the 312 members of the first term and 7843 questions and interpellations submitted by the 313 deputies of the next legislature.

In order to code localism and local issues we applied the methodology developed by the Comparative Policy Agendas Project (Baumgartner et al., 2006) and adapted by Martin (20II). Moreover, to better understand the personal vote strategies of the MPs, the local questions were coded using five subcategories corresponding to the types of actions that constituency service can be deconstructed to: casework (petitions), allocation responsiveness (local infrastructure questions), symbolic representation (questions about local events) and representation of local organized interests (with a further distinction between business and non-business interests).

Figure I below illustrates the mean number of the five types of constituency questions asked by the MPs that ran for re-election in the three cases. Thus, when a question dealt with a case surrounding individuals living in the MP's county, it was labeled 'petition'. The local organization category comprises both problems of local authorities and institutions (city halls, hospitals etc) and issues concerning local NGOs. If the question referred to public works such as road development, or renovating schools in the MP's county then it was included in the local infrastructure category. The last two categories included questions related to local businesses (e.g. problems of local farmers or industries) and local events (e.g. a local festival).

\section{Figure I about here}


Figure I highlights first and foremost the difference in the frequency of asking constituency questions that exists between the two Parliaments. Beyond this, one can observe the salience in all three contexts of questions about local infrastructure and local organizations. Also, questions about events taking place in the constituency are the least frequent of all.

\section{I The operationalization of the variables and the 'typical' MP}

Due to differences in parliamentary procedures and data availability, the parliamentary activity indexes do not include identical types of activities. Nevertheless, they enable a valid comparison between the overall amount of effort put by MPs in the law-making process, plenary debates and government scrutiny.

For the Romanian models the parliamentary activity index includes the number of bills, questions, no confidence motions, interventions in plenary debates and political statements made by the MP during the four years of mandate. Based on the effort they require, each bill and no confidence motion receives a weigh of three, while the other types of activity are weighed equally, an identical weighing to the one used in other articles dealing with the Romanian Parliament (Gherghina, 2016). For Hungary, the index includes the number of bills, bill amendments, questions, resolution proposals ${ }^{6}$ and political statements. Each bill is weighed 3 times higher than a question, resolutions and political statements are weighed I.5 times higher than questions, while each bill amendment is weighed 3 times lower than a question.

Because of the 2008 electoral reform in Romania the variable measuring electoral security at the previous election is operationalized slightly differently for the two time points. For 2008 I use the difference between the candidate's party list share of votes at county level at the 2004 parliamentary elections and Lijphart's effective electoral threshold [75/ (DM+I)] ${ }^{7}$. For 2012 the variable is computed as the difference between the candidate's share of votes in the SMD at the 2008 elections and Lijphart's effective electoral threshold. For the Hungarian model the variable indicates the difference between the candidate's party list share of votes at county level at the 2010 elections and Lijphart's effective electoral threshold.

The reference time for the dummy variable 'parliamentary office' is the entire term. This variable indicates whether the MP has been a committee chair or vice-chair, or had a leadership position in the parliamentary party group (PPG) or at House level. Last but not least, parliamentary experience measures the number of years the politician served as MP before the election under investigation. 'Minister' is a dummy for the MPs who held cabinet portfolio.

Of the 355 Romanian politicians who were members of the Chamber of Deputies at one point in time during the 2004-2008 mandate and who could have ran for re-election in 2008 only 230 did so. In 2012, $219^{8}$ of the 312 members of the Chamber of Deputies who could have ran for re-election, did participate in the contest.

Similarly, of the 403 Hungarian politicians who served as MPs at one point during the 20102014 legislative cycle only 277 ran for re-election. Of these, 164 ran both in SMDs and on the national lists, while 108 ran solely on the national lists. For the 106 SMDs competed 169 incumbent MPs. Most of them (96) were nominated by the governing coalition of Fidesz and KDNP. Next came Jobbik which nominated 35 incumbent MPs as district candidates. The Unity

\footnotetext{
${ }^{6}$ In Hungarian, 'határozati javaslat'.

${ }^{7}$ DM stands for the district magnitude.

${ }^{8}$ The regression analyses presented below include only those MPs running for re-election in the Chamber of Deputies: 180 in 2008 and 203 in 2012.
} 
electoral alliance nominated 33 MPs as SMD candidates. Finally, LMP had 4 MPs among its district candidates and $\mathrm{KTI}^{9}$ had I.

The 'typical' MP in the three samples asked 4 constituency questions in Hungary and between 9 (2008) and almost II (20I2) in Romania. Their mean vote shares varied between 35 - 36\% (Romania 2008 and Hungary 2014) and 47\% (Romania 20I2). The parliamentary experience levels are rather similar: on average the Romanian MPs had been in the legislature for 6.5 (2008) up to 6.7 years (20I2) before the analyzed election, whereas the average incumbent running for re-election in an SMD in Hungary in 2014 had 8.6 years of such experience. Holding a parliamentary office was an experience shared by one third (Romania 2012 and Hungary 2014) up to almost half of the incumbent candidates (Romania 2008). Only between 6 and 8\% of the MPs in the samples served in the government in the analyzed terms. For the complete descriptive statistics see Table 3 in the Appendix.

\section{How do voters learn about constituency questions?}

Voter demand for service is most likely a major factor in the MPs' pursuit of a personal vote. One indicator of the former is how many voters correctly recall the name of their representative(s). Drawing on Comparative Study of Electoral Systems data, Curtice and Phillips Shively (2009) show that $64 \%$ of the Hungarian ${ }^{10}$ respondents and $31 \%$ of the Romanian respondents could correctly name a candidate running in parliamentary elections in their district. For Romania, this data comes from the closed list PR era. According to a more recent survey (Romanian Election Studies, 20II) carried after the electoral reform almost $46 \%$ of the respondents declared they know the MP elected in their district.

Beyond MP name recall, the first hypothesis presented above is dependent on voters learning about the constituency work of their representatives. Although research on the so-called 'presentational styles', i.e. how legislators present and explain their work to constituents, is lacking in Romania and Hungary, our analysis of online resources and parliamentary surveys revealed that the MPs in the two countries are quite active in this respect, frequently trying to reach out to voters as well as to local and national media. One could be skeptical about such efforts given that the media in the two countries are perceived as having a weak political information commitment (Popescu and Toka, 20I2), while sizable parts of the electorate display relatively low levels of political knowledge.

Nevertheless, in Romania many MPs highlight on their websites the number and content of their parliamentary questions dealing with issues from their constituency and local newspapers also cover this type of activities. The coverage is often triggered by press statements released by MPs for the local media following actions on local issues. Moreover, some MPs regularly send their constituents 'activity report' leaflets.

This type of advertising is of course more frequent during campaigns: 'It is very common that campaign materials such as leaflets contain both the number of local questions and interpellations and

\footnotetext{
${ }^{9}$ Community for Social Justice People's Party, a fringe party founded by the former MSZP MP and Speaker of the Hungarian Parliament, Katalin Szili.

${ }^{10}$ The fact that almost $5 \%$ of the respondents of a post electoral-survey conducted in 2006 (Toka et al., 2006) indicated that they voted for a candidate affiliated with a different party than the one they voted for in the list tier is further evidence that there is a personal vote potential in Hungary.
} 
their topics, so that voters can find out directly at election time about the constituency service efforts of the MPs', argued a political marketing consultant working for a number of Romanian MPs. "I

The MPs' practice of advertising parliamentary questions on personal websites and social media accounts is also present in Hungary. There, two national news portals cover extensively the MPs' parliamentary questions and interpellations: www.gondola.hu and www.hvg.hu and there is also an website that presents legislator activities in a very comprehensive manner: kepviselofigyelo.hu. Additionally, the national and county branches' party websites especially those of Jobbik, MSZP and KNDP also present parliamentary questions.

Further evidence on media coverage of questions and the mechanisms behind it comes from a parliamentary survey. Thus, based on the answers given by Hungarian MPs to the PARTIREP Survey (Deschouwer and Depauw, 20I4), it seems that on average they inform the media about almost two thirds (64\%) of their initiatives: bills, written and oral questions. Furthermore, the MPs estimated that the media covers, on average, $55 \%$ of these initiatives.

\section{The electoral value of constituency questions}

Substantial shares of MPs consider the constituency as their main focus of representation: $47 \%$ in Hungary and 31\% in Romania (Chiru and Enyedi, 2015). However, the conventional view is that national party competition is what drives voting behavior in both countries (Enyedi and Toka, 2007; Pop-Eleches, 2010), therefore finding evidence that constituency-centered legislative behavior is rewarded by voters would be remarkable in itself.

As it can be seen from the model fit of the regressions presented in tables I and 2, a fair share of the vote in the two countries is explained by the party affiliation of the MP. Nevertheless, there is still some room for a personal vote as emphasized by the effects of the variables capturing parliamentary activities and roles.

At the first elections organized Romania in SMDs after 1989, one constituency question brought the MP seeking re-election approximately 29 votes or an increase of $0.08 \%$ in vote share. The effect is rather remarkable, especially since the index of parliamentary activities produces a negative effect. It seems that more engagement in parliamentary activities brings fewer votes. Nevertheless, it turns out that the most active MPs are those that were elected from the safest list positions at the 2004 elections (Pearson's $\mathrm{R}=0.462^{* * *}$ ). Given that electoral security tends to reproduce itself (see the positive large effect of 'Electoral security 2004' in Table I) parliamentarians who were elected by small margins are better off investing time in non-legislative (constituency service and pork barrel) rather than legislative activities.

The positive contribution of constituency questions is also robust to other, more comprehensive model specifications. Thus, in models not shown here I also controlled for local politics experience, party switching and average parliamentary vote attendance, and the effect of constituency questions remained virtually the same.

Table 2 shows that the positive effect of constituency questioning was also registered at the 2012 elections. Nevertheless, the expectation formulated by hypothesis 3 is also corroborated, this effect being smaller than in 2008. As mentioned already, the 2012 election were marked by the huge unpopularity of the former governing party and by the formation of a pre-electoral alliance between the other two major parties. Given these elements one would expect more than ever voters to reward or punish candidates based on their party affiliation, while considerations about individual MPs' activity record to be mostly ignored.

\footnotetext{
II Interview with S.S. (June I8th, 20I5).
} 
Indeed, the model including the party affiliation dummies has a very high explanatory power: it accounts for up to $84 \%$ of the variance. However, the importance of constituency service for winning votes remains a valid finding. Thus, the full model shows that for each additional constituency question asked, an MP running for re-election received around 17 votes, or a share increase of $0.04 \%$. In contrast, the overall parliamentary effort does not make a difference.

\section{Table I about here}

In order to make the interpretation of the main findings more straightforward I used the STATA program Clarify (King et al., 2000), with which I run simulations based on the second model for each election. Figure 2 plots the expected values of vote percentage with $95 \%$ confidence intervals against the number of constituency questions, while keeping all other variables at their mean. In both cases the increases in vote share are remarkable.

\section{Figure 2 about here}

As expected, given the context of the 2014 elections in Hungary, the model including the party affiliation dummies has a very high explanatory power: it explains $81 \%$ of the variance. The most salient finding of Table 2 is that constituency questions did not help Hungarian MPs win more votes at the 2014 parliamentary elections.

\section{Table 2 about here}

Figure 3 plots the results of the simulations made with Clarify, based on the second model in Table 2. All other independent variables were held at their mean and the expected vote shares are bounded by $95 \%$ confidence intervals. The line is virtually flat: asking constituency questions does not increase the vote share and it does not decrease it either.

The very special nature of the election with its limited potential for a personal vote, discussed above is certainly part of the explanation for this non-finding. Beyond this peculiarity, one also has to keep in mind that electoral competition was extremely party-centered in Hungary throughout the post-communist period. Thus, in an article that analyzed the impact of the Hungarian candidates' personal vote earning attributes on their vote shares at five parliamentary elections held between 1994 and 2010, Papp (2017) found that party vote share alone [at county level] explains $93 \%$ of the overall variation in candidate vote share.

\section{Figure 3 about here}

Within the boundaries of this limited personal vote potential, one key factor at the 2014 elections appears to have been the better name recognition of MPs who served in the government and of those who held parliamentary office. These MPs gained significantly more votes than their colleagues while at the same time they were not among the most active in asking constituency questions. Moreover, previous electoral security also played an important role in the re-election process and it is safe to assume that these MPs also had better access to nominations in safer, or at least more party-friendly districts given the traditional choice of 
Hungarian parties to secure the re-election of their high-level parliamentary cadres (llonszki and Schwarcz, 2013). The non-significance of the overall parliamentary effort also suggests that resources such as good relations with party gatekeepers or the higher visibility that comes with being a cabinet member or holding a parliamentary office were overall more important for electoral performance than actual parliamentary activities.

Then, why do Hungarian MPs even bother to ask constituency questions? Constituency service engagement might be motivated by the desire to keep track of the real problems the citizens face, and by the psychological satisfaction derived by MPs from it and less by electoral gain. Thus, $47 \%$ of the Hungarian MPs responding to the PARTIREP Survey (Deschouwer and Depauw, 2014) agreed that reducing the efforts they make to assist voters in their dealings with public authorities would result in 'losing a significant number of votes', whereas $53 \%$ thought their party would lose votes. Instead, $88 \%$ agreed that a result of the same action, i.e. a reduction in casework would result in 'los[ing] touch with the problems voters face in their daily lives'.

In models not shown here I re-ran the regressions on samples including only the MPs who sought re-election in the same county they were elected as parliamentarians. The main effects related to asking constituency questions and their magnitude remained extremely similar for all three cases.

\section{Conclusion}

The article evaluates for the first time the electoral consequences of initiating constituency questions. It does so in a comparative perspective, using data from three elections in which the potential for personal vote varied considerably. The evidence derived from our analyses corroborates the idea that constituency questions can help MPs win votes, provided that the electoral system provisions enable a personal vote and the electoral debate is not entirely focused on the parties' record in office.

The fact that politicians campaign on their constituency service efforts and that citizens reward them for such activities, at least in Romania, can be interpreted as evidence that what this article studies is genuine accountability, given the various normative concerns that nonprogrammatic linkages usually trigger (e.g. the specter of clientelism).

Further studies could investigate in more detail the mechanisms through which constituency questions help MPs win more votes. In doing so, one promising line of research would be to rely on survey data measuring not only citizens' perceptions of their representatives but also their knowledge of the latter parliamentary activities. 
Table I The impact of constituency questions on vote in Romania

\begin{tabular}{|c|c|c|c|c|c|}
\hline & $\begin{array}{l}\text { Vote \% } \\
2008 \text { (I) }\end{array}$ & $\begin{array}{l}\text { Vote \% } \\
2008(2)\end{array}$ & & $\begin{array}{l}\text { Vote } \% \\
2012(1)\end{array}$ & $\begin{array}{l}\text { Vote } \% \\
2012(2)\end{array}$ \\
\hline Constituency Questions & $\begin{array}{l}0.10 I^{* * * *} \\
(0.031)\end{array}$ & $\begin{array}{l}0.08 I^{* * * *} \\
(0.027)\end{array}$ & Constituency Questions & $\begin{array}{l}0.110 * * * \\
(0.035)\end{array}$ & $\begin{array}{l}0.044 * * * \\
(0.012)\end{array}$ \\
\hline $\begin{array}{l}\text { Parliamentary activity } \\
\text { index }\end{array}$ & $\begin{array}{l}-0.004 * * * \\
(0.001)\end{array}$ & $\begin{array}{l}-0.002^{* *} \\
(0.001)\end{array}$ & $\begin{array}{l}\text { Parliamentary activity } \\
\text { index }\end{array}$ & $\begin{array}{l}-0.002^{* *} \\
(0.001)\end{array}$ & $\begin{array}{l}0.000 \\
(0.000)\end{array}$ \\
\hline Years in Parliament & $\begin{array}{l}0.954 * * * \\
(0.334)\end{array}$ & $\begin{array}{l}0.837 * * * \\
(0.286)\end{array}$ & Years in Parliament & $\begin{array}{l}1.021 * * * \\
(0.315)\end{array}$ & $\begin{array}{l}0.492 * * * \\
(0.157)\end{array}$ \\
\hline Parliamentary office & $\begin{array}{l}1.634 \\
(2.282)\end{array}$ & $\begin{array}{l}1.520 \\
(1.933)\end{array}$ & Parliamentary office & $\begin{array}{l}-5.055^{*} \\
(2.975)\end{array}$ & $\begin{array}{l}-2.480^{*} \\
(1.473)\end{array}$ \\
\hline Electoral security 2004 & $\begin{array}{l}0.723 * * * \\
(0.098)\end{array}$ & $\begin{array}{l}0.431 * * * \\
(0.121)\end{array}$ & Electoral security 2008 & $\begin{array}{l}0.450 * * * \\
(0.109)\end{array}$ & $\begin{array}{l}0.463 * * * \\
(0.060)\end{array}$ \\
\hline Minister & $\begin{array}{l}\text { II } 1.498^{* * * *} \\
(4.173)\end{array}$ & $\begin{array}{l}15.57 \mid \text { |*** } \\
(4.531)\end{array}$ & Minister & $\begin{array}{l}-0.293 \\
(5.272)\end{array}$ & $\begin{array}{l}5.472 * \\
(2.874)\end{array}$ \\
\hline Woman & $\begin{array}{l}-0.951 \\
(3.505)\end{array}$ & $\begin{array}{l}-2.126 \\
(3.188)\end{array}$ & Woman & $\begin{array}{l}-1.295 \\
(4.565)\end{array}$ & $\begin{array}{l}0.925 \\
(1.883)\end{array}$ \\
\hline PNL & & $\begin{array}{l}-10.708 * * * \\
(3.182)\end{array}$ & ARD & & $\begin{array}{l}-39.311 \text { I*** } \\
(1.35 I)\end{array}$ \\
\hline PRM & & $\begin{array}{l}-26.018^{* * * *} \\
(3.136)\end{array}$ & PPDD & & $\begin{array}{l}-40.397 * * * \\
(2.339)\end{array}$ \\
\hline PSD-PC & & $\begin{array}{l}-0.730 \\
(2.350)\end{array}$ & UDMR & & $\begin{array}{l}-23.725 * * * \\
(3.686)\end{array}$ \\
\hline UDMR & & $\begin{array}{l}6.512 \\
(5.632)\end{array}$ & & & \\
\hline Constant & $\begin{array}{l}9.825 * * * \\
(3.138)\end{array}$ & $\begin{array}{l}22.145^{* * * *} \\
(3.844)\end{array}$ & Constant & $\begin{array}{l}38.886 * * * \\
(3.090)\end{array}$ & $\begin{array}{l}56.223 * * * \\
(1.691)\end{array}$ \\
\hline $\mathrm{R}^{2}$ & .338 & .507 & $\mathrm{R}^{2}$ & .160 & .841 \\
\hline Observations & 180 & 180 & Observations & 203 & 203 \\
\hline
\end{tabular}

* Significance at * $p<0.10, * * p<0.05, * * * p<0.01$

$* *$ Robust standard errors in parentheses. 
Table 2 The impact of constituency questions on vote (Hungary 2014) Vote $\%$ Vote $\%$

(1) (2)

\begin{tabular}{|c|c|c|}
\hline Constituency Questions & $\begin{array}{l}0.08 \mathrm{I} \\
(0.065)\end{array}$ & $\begin{array}{l}0.021 \\
(0.056)\end{array}$ \\
\hline Parliamentary activity & 0.000 & -0.003 \\
\hline index & $(0.005)$ & $(0.004)$ \\
\hline Years in Parliament & $\begin{array}{l}0.100 \\
(0.079)\end{array}$ & $\begin{array}{l}-0.066 \\
(0.080)\end{array}$ \\
\hline Parliamentary office & $\begin{array}{l}1.548 \\
(1.099)\end{array}$ & $\begin{array}{l}2.483 * * \\
(0.984)\end{array}$ \\
\hline Electoral security 2010 & $\begin{array}{l}0.642 * * * \\
(0.037)\end{array}$ & $\begin{array}{l}0.523 * * * \\
(0.073)\end{array}$ \\
\hline Minister & $\begin{array}{l}2.316^{*} \\
(1.34 I)\end{array}$ & $\begin{array}{l}3.087^{* *} \\
(1.366)\end{array}$ \\
\hline Woman & $\begin{array}{l}-3.796 \\
(2.533)\end{array}$ & $\begin{array}{l}-2.575 \\
(2.242)\end{array}$ \\
\hline Unity & & $\begin{array}{l}0.752 \\
(2.709)\end{array}$ \\
\hline Jobbik & & $\begin{array}{l}-5.334^{*} \\
(2.707)\end{array}$ \\
\hline LMP & & $\begin{array}{l}-15.637^{* * *} \\
(3.524)\end{array}$ \\
\hline KTI & & $\begin{array}{l}-15.363 * * * \\
(4.060)\end{array}$ \\
\hline Constant & $\begin{array}{l}16.666 \text { *** } \\
(1.505)\end{array}$ & $\begin{array}{l}22.95 I^{* * * *} \\
(3.190)\end{array}$ \\
\hline $\mathrm{R}^{2}$ & .773 & .810 \\
\hline Observations & 169 & 169 \\
\hline
\end{tabular}




\section{Appendix}

Table 3 Descriptive statistics of dependent variable and covariates

\begin{tabular}{lrrrrr}
\hline & Mean & Std. deviation & Min. & Max. & N \\
\hline Vote \% Romania 2008 & 35.10 & 17.86 & 0.55 & 89.35 & 180 \\
Vote \% Romania 20I2 & 46.90 & 22.09 & 4.73 & 87.66 & 203 \\
Vote \% Hungary 20I4 & 35.94 & 13.02 & 0.53 & 60.62 & 169 \\
N. constituency questions Ro. 2008 & 8.99 & 20.09 & 0 & 234 & 180 \\
N. constituency questions Ro. 20I2 & 10.76 & 26.89 & 0 & 294 & 203 \\
N. constituency questions Hu. 20I4 & 3.95 & 9.31 & 0 & 64 & 169 \\
Parl. activity index Romania 2008 & 316.89 & 626.23 & 30 & 7603 & 180 \\
Parl. activity index Romania 20I2 & 346.38 & 700.92 & 36 & 8802 & 203 \\
Parl. activity index Hungary 20I4 & 123.66 & 153.83 & 3 & 881.83 & 169 \\
Years in Parliament Romania 2008 & 6.58 & 3.77 & 4 & 18 & 180 \\
Years in Parliament Romania 20I2 & 6.72 & 4.25 & 4 & 22 & 203 \\
Years in Parliament Hungary 20I4 & 8.64 & 5.73 & 2.53 & 24 & 169 \\
Parliamentary office Romania 2008 & 0.47 & 0.50 & 0 & 1 & 180 \\
Parliamentary office Romania 20I2 & 0.30 & 0.46 & 0 & $\mathrm{I}$ & 203 \\
Parliamentary office Hungary 20I4 & 0.31 & 0.47 & 0 & $\mathrm{I}$ & 169 \\
Electoral security Romania 2008 & 25.34 & 12.57 & -7.36 & 65.52 & 180 \\
Electoral security Romania 20I2 & 5.31 & 13.83 & -31.08 & 51.85 & 203 \\
Electoral security Hungary 20I4 & 27.44 & 17.62 & -12.5 & 52.12 & 169 \\
Minister Romania 2008 & 0.07 & 0,25 & 0 & $\mathrm{I}$ & 180 \\
Minister Romania 20I2 & 0.08 & 0,27 & 0 & $\mathrm{I}$ & 203 \\
Minister Hungary 20I4 & 0.09 & 0.29 & 0 & $\mathrm{I}$ & 169 \\
Woman Romania 2008 & 0.10 & 0.30 & 0 & $\mathrm{I}$ & 180 \\
Woman Romania 20I2 & 0.12 & 0.33 & 0 & $\mathrm{I}$ & 203 \\
Woman Hungary 20I4 & 0.07 & 0.26 & 0 & $\mathrm{I}$ & 169 \\
\hline
\end{tabular}


Figure I Mean number of constituency questions by issue

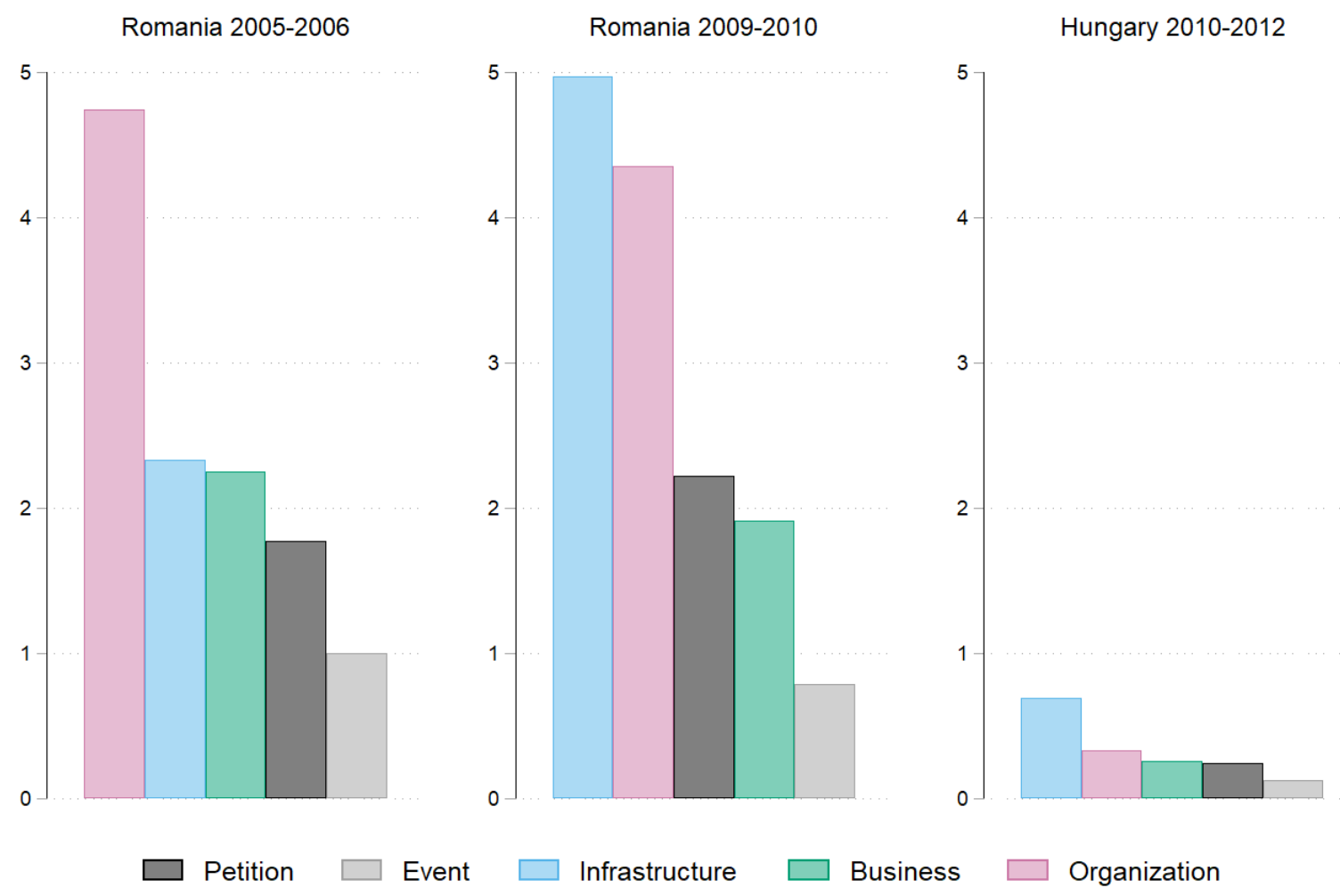


Figure 2 Changes in vote percentage based on the number of constituency questions (Romania)

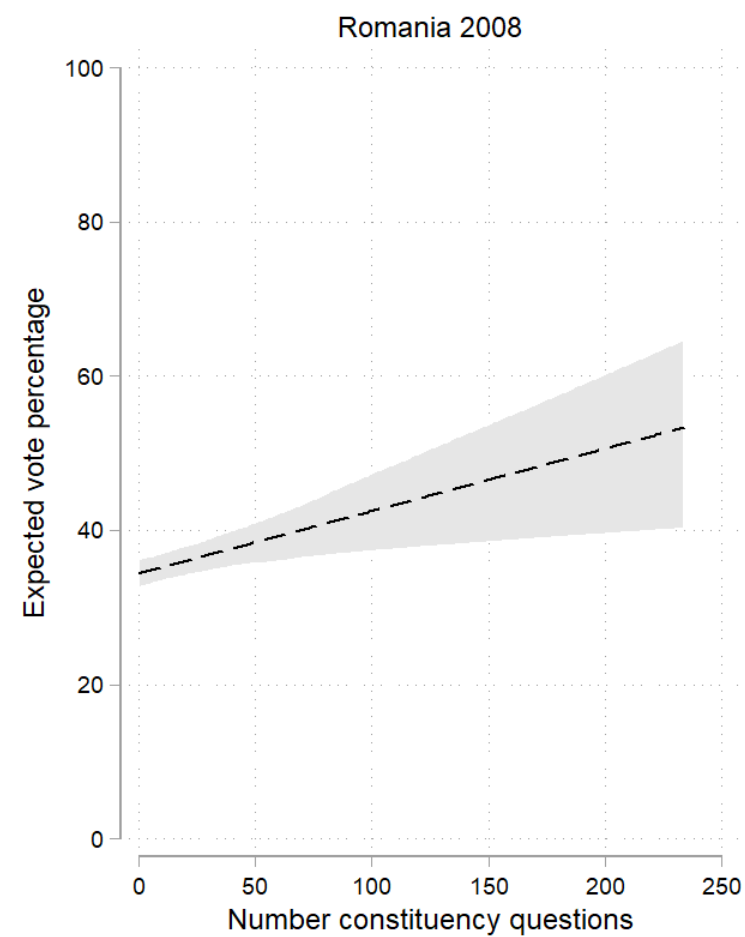

All other independent variables held at their mean

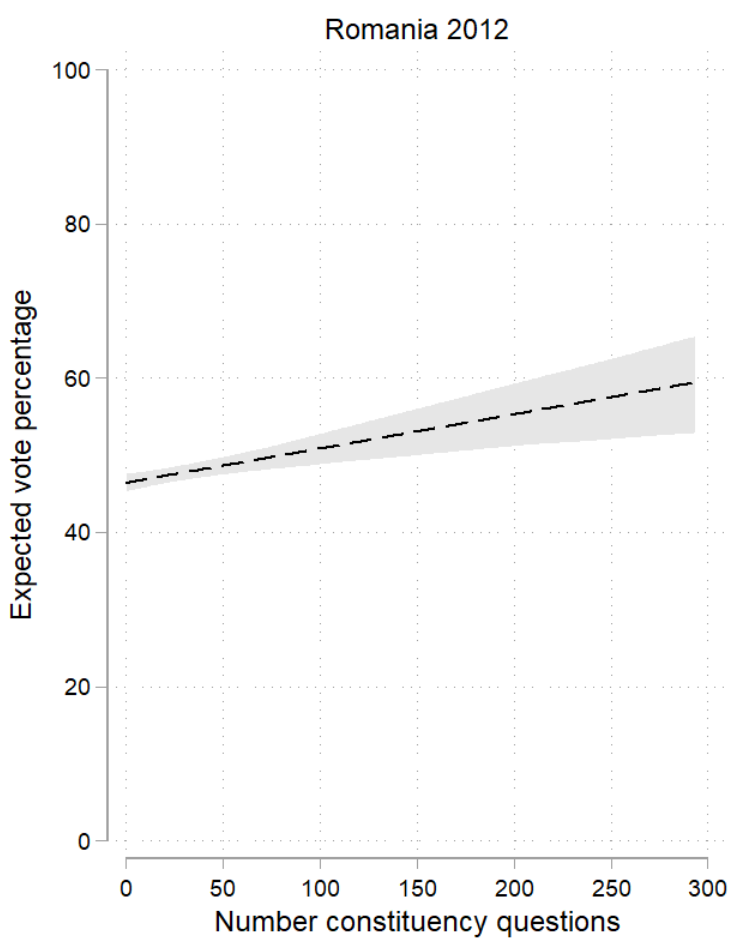

All other independent variables held at their mean 
Figure 3 Changes in vote share based on the number of constituency questions (Hungary 2014)

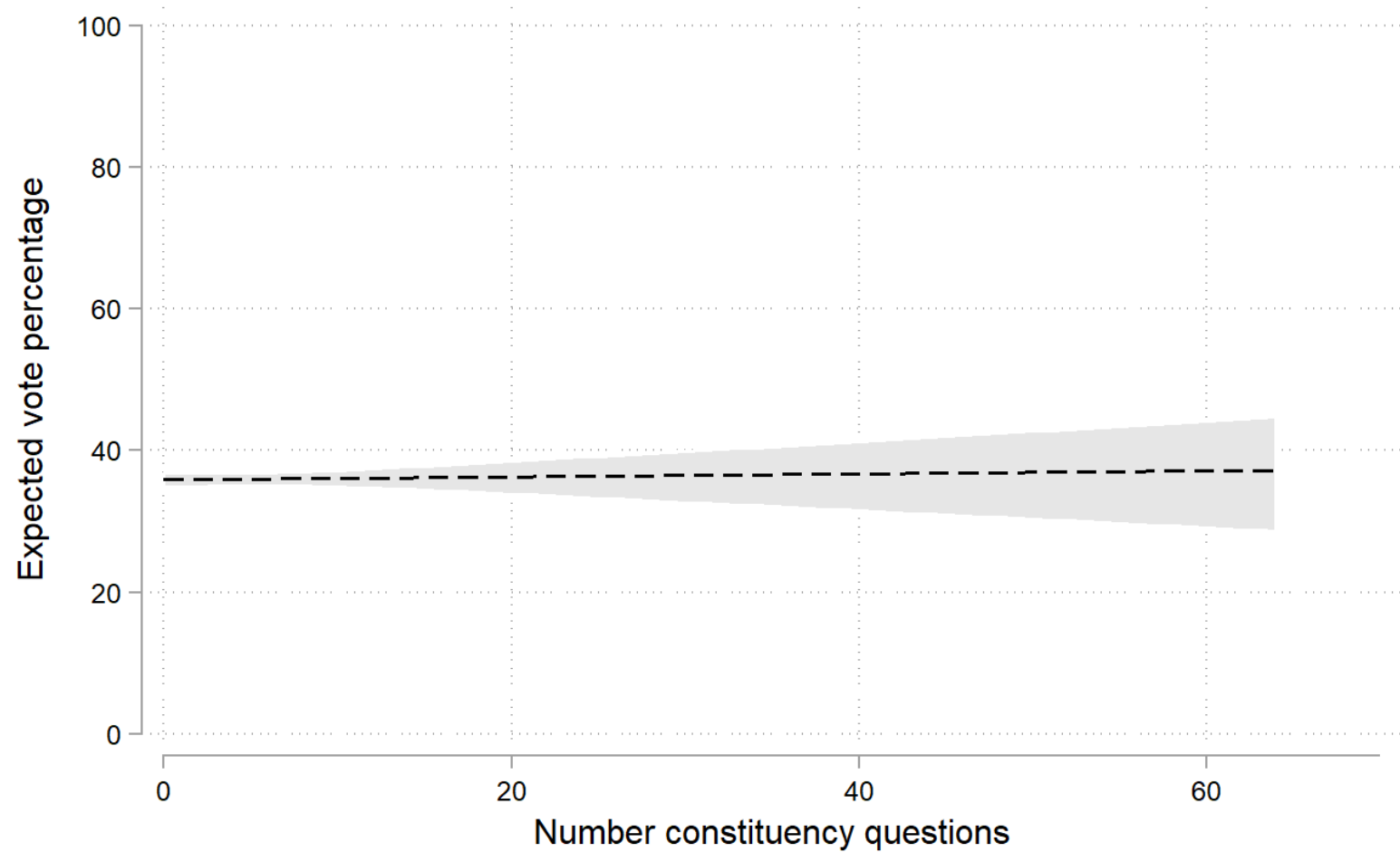

All other independent variables held at their mean 


\section{References}

André, A., Depauw, S. and Martin, S., (2016) 'The classification of electoral systems: Bringing legislators back in', Electoral Studies, 42, 42-53.

Arter, D. (20I I) 'The Michael Marsh question: How do Finns do constituency service?', Parliamentary Affairs, 64, I29-I52.

Akirav, O. (20I5) 'Re-election: Different Skills for Different Roles', Government and Opposition, 50, 90-II8.

Baumgartner, F.R., Green-Pedersen, C. and B.D. Iones. (2006) 'Comparative Studies of Policy Agendas', lournal of European Public Policy, I3, 955-970.

Bowler, S. (2010) 'Private members' bills in the UK Parliament: Is there an 'electoral connection'?', The lournal of Legislative Studies, I 6, 476-494.

Box-Steffensmeier, J. M., Kimball, D. C., Meinke, S. R. and Tate, K. (2003) 'The effects of political representation on the electoral advantages of House incumbents', Political Research Quarterly, 56, 259-270.

Carey, J. M. and Shugart, M. S. (I995) 'Incentives to cultivate a personal vote: A rank ordering of electoral formulas', Electoral Studies, I4, 4I7-439.

Chiru, M. and Enyedi, Z. (2015) Choosing your own boss: Variations of representation foci in mixed electoral systems, The lournal of Legislative Studies, 2 I, 495-5I 4.

Cover, A. D., and Brumberg, B. S. ( 1982) 'Baby books and ballots: The impact of congressional mail on constituent opinion'. The American Political Science Review, 76(2): 347-359.

Cox, G. W. and Katz, J. (1996) 'Why Did the Incumbency Advantage in U.S. House Elections Grow?' American Journal of Political Science, 40, 478-97.

Curtice, J.K. and Phillips Shively, W. (2009) 'Who represents us best? : one member or many?'. In: Klingemann, H.D. (ed.) The Comparative Study of Electoral Systems. Oxford: Oxford University Press, PP. I7I-I92

Deschouwer, K. and Depauw, S. (eds.) (2014) Representing the People: a Survey among Members of Statewide and Substate Parliaments. Oxford: Oxford University Press.

Däubler, T., Bräuninger, T. and Brunner, M. (2016) 'Is Personal Vote-Seeking Behavior Effective', Legislative Studies Quarterly, 4 I, 4I9-444.

Enyedi, Z. and Toka, G. (2007) 'The only game in town: Party politics in Hungary'. In White, S., and Webb, P. (eds.), Party Politics in New Democracies. Oxford: Oxford University Press, pp. |47-I78.

Fiorina, M. P. (I98I) 'Some Problems in Studying the Effects of Resource Allocation in Congressional Elections', American Journal of Political Science, 25, 543-567.

Giugal, A., lohnston, R., Chiru, M., Ciobanu, I. and Gavris, A. (2017) 'Gerrymandering and Malapportionment, Romanian Style: The 2008 Electoral System', East European Politics and Societies, 3 I, 683-703.

Gelman, A. and Huang, Z. (2008) 'Estimating Incumbency Advantage and Its Variation, as an Example of a Before-After Study', Journal of the American Statistical Association, I 03, 437 46.

Gherghina, S. (2016) 'Rewarding the 'traitors'? Legislative defection and re-election in Romania', Party Politics, 22, 490-500.

Grimmer, J., Westwood, S. J. and Messing, S. (2014) The Impression of Influence: Legislator Communication, Representation, and Democratic Accountability, Princeton, Princeton University Press. 
Ilonszki, G., and Papp Z. (20I4). 'Parliamentary Questions in Hungary 20I0-20I2', machine readable data file.

Ilonszki, G. and Schwarcz, A. (2013) 'Hungarian MPs in the context of political transformation'. In Semenova, E., Edinger, M., and Best, H. (eds.) Parliamentary Elites in Central and Eastern Europe: Recruitment and Representation, New York: Routledge, pp. 54-73.

Ilonszki, G. and Várnagy, R., (20l6) 'Parliamentary elections in Hungary, 20I4', Electoral Studies, 43, I69-172.

Johannes, J. R. and McAdams, J. C. (198I) 'The Congressional Incumbency Effect: Is It Casework, Policy Compatibility, or Something Else? An Examination of the 1978 Election', American Journal of Political Science, 25, 512-42.

Johnson, J. and Barnes, A. (20I5) 'Financial nationalism and its international enablers: The Hungarian experience', Review of International Political Economy, 22, 535-569.

King, G. (I99I) 'Constituency service and incumbency advantage', British Journal of Political Science, 2 I, II9-128.

King, G., Tomz, M. and Wittenberg, I. (2000) 'Making the most of statistical analyses: Improving interpretation and presentation', American Journal of Political Science, 44, 347-36I.

Martin, S. (2010) 'Electoral rewards for personal vote cultivation under PR-STV', West European Politics, 33, 369-380.

Martin, S. (20II) 'Parliamentary Questions, the Behaviour of Legislators, and the Function of Legislatures: An Introduction', The Journal of Legislative Studies, I 7, 259-270.

Mayhew, D. R. (1974) Congress: The electoral connection. New Haven, CT: Yale University Press.

McAdams, J. C., and Johannes, J. R. (1988) 'Congressmen, Perquisites, and Elections'. Journal of Politics, 50, 4I 2-39.

Mudde, C. (2014) 'The 2014 Hungarian parliamentary elections, or how to craft a constitutional majority', Monkey Cage blog, last accessed at: https://www.washingtonpost.com/news/monkey-cage/wp/2014/04/I4/the-20 I4hungarian-parliamentary-elections-or-how-to-craft-a-constitutionalmajority/?utm term=.9d8789b9d05c on 25 October 2017

Papp, Z. 2017. 'Challenging the Odds: Incumbency Disadvantage, Local Ties, and Electoral Performance in Hungary, 1994-2010', East European Politics and Societies, DOI: 10.1177/08883254I7725785

Parker, D. and Goodman, G (2009) 'Making a good impression: Resource allocation, home styles, and Washington work', Legislative Studies Quarterly, 34, 493-524.

Pop-Eleches, G. (20I0). 'Throwing out the bums: Protest voting and unorthodox parties after communism', World Politics, 62, 221-260.

Popescu, M. and Toka, G. (20I2) 'How do Media Systems Influence Citizens' Political Knowledge and the Social Inequalities of Knowledge?', paper presented at the ECPR JS, Antwerp, 10-15 April.

Rivers, D. and Fiorina, M. P. (1992) 'Constituency service, reputation, and the incumbency advantage'. In Fiorina, M. P. and Rohde, D. W. (eds.), Home Style and Washington Work: Studies of Congressional Politics, Ann Arbor: University of Michigan Press pp. I7-45.

Shugart, M. S. (2005) 'Comparative electoral systems research: the maturation of a field and new challenges ahead'. In Gallagher, M. and Mitchell, P. (eds.) The Politics of Electoral Systems, Oxford: Oxford University Press, pp. 25-55.

Toka G., Tardos, R. and Angelusz, R. (2014) Hungarian Election Study 2006, postelection wave. 
Toka, G. (2014) 'Constitutional Principles and Electoral Democracy in Hungary', in Bos, E. and Pócza, K. (eds.), Constitution Building in Consolidated Democracies: A New Beginning or Decay of a Political System? Baden-Baden: Nomos Verlag pp. 309-329.

Wallack, J. S., Gaviria, A., Panizza, U., and Stein, E. (2003) 'Particularism around the World', The World Bank Economic Review, 17, 133-43.

*** Romanian Election Studies (20II) Soros Foundation Romania. Bucharest. 